\title{
Histories of family health
}

\section{Citation}

Rothschild, Emma. 2014. “Histories of Family Health." The Lancet 383 (9916) (February): 506507. doi:10.1016/s0140-6736(14)60173-2. http://dx.doi.org/10.1016/S0140-6736(14)60173-2.

\section{Published Version}

doi:10.1016/s0140-6736(14)60173-2

\section{Permanent link}

http://nrs.harvard.edu/urn-3:HUL.InstRepos:11857762

\section{Terms of Use}

This article was downloaded from Harvard University's DASH repository, and is made available under the terms and conditions applicable to Open Access Policy Articles, as set forth at http:// nrs.harvard.edu/urn-3:HUL.InstRepos:dash.current.terms-of-use\#OAP

\section{Share Your Story}

The Harvard community has made this article openly available.

Please share how this access benefits you. Submit a story.

Accessibility 
The Art of Medicine

Histories of Family Health

\section{Emma Rothschild}

History is a way of entering "into the very circumstances of the actors, we feel for them as it were for ourselves" - in Adam Smith's description, in a lecture in 1763 - and it is also the discovery of distance. Individuals in the past, who are like figures seen at a vast distance, are at the same time eerily close; people like us.

This sense of disorientation, of historical figures as very different and very similar, or as oscillating between distance and closeness, is intense in relation to health and illness. Like economic history, the history of medicine has been a specialized sub-discipline, the story of a particular side of life, and of how it changes over time. But health, like economic experience, is also part of the ordinary lives of individuals and families. The sicknesses of people in the past were like ours. Like us, they lived in families, sought information about their own and their friends' health, and were anxious about the relationship between the body and the mind. As Charles Rosenberg has written, medicine is "timeless and time-bound."

There are moments, in histories of medicine or public health, when individuals in the past suddenly come to life, in domestic as well as institutional settings. A study of the 1918 influenza epidemic in Southeast Asia describes a flu victim in Malaya who "was taken by his mother to European doctors, Chinese druggists and Siamese bomohs;" others were only brought to hospitals when they were dying, "finding their impersonal care and isolation from family entirely alien." A study of $20^{\text {th }}$-century international public health quotes an inquiry into the reasons that patients gave 
for failing to comply with treatments for tuberculosis, in Bangalore in 1963: "'Health visitor behaved very rudely'... 'I was advised special diet I could not afford.’”

There are also moments when other histories, including economic history and the microhistory of family life, become stories of medicine and health. The Johnstones, for example, were a large, disputatious Scottish family in the $18^{\text {th }}$ century, friends or acquaintances of Adam Smith. Four of the sisters and seven brothers survived infancy and they were for the most part strikingly resilient. "Poor Betty had been taken ill of the particulars attending a Cholera Morbis," and was rheumatic, unable to "walk about without Pain," their father wrote of one of the sisters, in 1772. Almost forty years later, at the age of 80 , Betty reported to her niece that "I find nothing does me so much good as exercise." The Johnstones wrote to each other amazingly often about what they described as their "state of health," and their illnesses were redoubtable. "I was seized all at once with that species of a Putrid Fever called Mille Harpies," James wrote to his brother John (about an otherwise unidentified ailment); to his sister Charlotte's husband, he wrote "I have been almost dead and what is worse rotten before I was dead." They had cold feet and swollen legs, "flatus" and "lowness." Their remedies were repulsive; "my father... was bled blistered vomited \& had three doses of rhubarb," Charlotte reported to their brother William, and asked him to lend her sixpence, to buy "elixir of vitriol."

There are three respects, all the same, in which the Johnstones' world of health is reminiscent of our own; and in which the assumptions of their times may even have become closer to $21^{\text {st }}$-century ways of thinking about health and disease. The first respect has to do with the extraordinary diversity of the Johnstones' sources of information about medicine and health. One of their contemporaries described the late eighteenth century as "this age of information," and the 
brothers and sisters gathered pieces of medical information, or misinformation, from the most disparate authorities. They owned medical books (the Cure of Diseases of Body \& Mind was valued at fourpence in an inventory after James's death), consulted an uncle whom they considered to be experienced in the illnesses of the mind, invested in heavily-advertised patent medicines (Velnos' Vegetable Syrup), took medicinal red wine as prescribed by "our apothecary," and followed the recommendations of their friends (as to "the extraordinary effect of semiruta in Putrid Fevers.") They occasionally had expensive consultations by correspondence with prominent physicians. Their father, in the summer of 1751, offered to supply Adam Smith with "goat whey," a common remedy for debilitation. They had business and social relationships with medical families, including the family of Dr William Cullen, who treated typhus, a "nervous fever," who treated typhus, a "nervous fever", with blood-letting, "antiphlogistic measures", and the avoidance of "all impressions which lead to thought."

The second respect in which the Johnstones' lives are so familiar is in the extent to which illness was itself a family condition. The brothers and sisters were each others' "care-givers," in modern terms. The "only thing [that] gives him ease... seems to be Chafing his head with our hands $\&$ the Opium," John wrote to William, about George, when the brothers were in their 50s. The experienced uncle described the effects on the children of their father's last illness, with John himself becoming ill, and then "waiting for Bettys recovery, (for Grief \& fatigue had brought on her old distemper), \& she for his. They went away together." The family consulted each other about remedies and symptoms and diet, inherited tendencies and memories of childhood exercise. They wrote letters about loss, or the expectation of loss, which they considered to be an indication of risk. The siblings were unusual in the extent and the intimacy of their exchanges. But this in itself makes 
them oddly modern. It is as though their letters about how they felt - some of which took as much as a year to reach home, when five of the seven brothers ventured to the edges of the British empire - were the equivalents of status updates or emails or late night phone conversations. As their mother, who attributed her own excellent health to the fact that she had "continued so long on the breast," wrote in 1764 in a letter to John, whom she believed to be in Bengal, "You had one expression struck me, you say fifteen years in Indies has made a great change in your constitution it ought to be now in its prime all it can afford you is not worth risking it oh come home."

The Johnstones are familiar, thirdly, because of their preoccupation with the changing relationship between the body and the mind. This was in general a more prominent theme of medical literature than it is now: The Natural Method of Curing the Diseases of the Body, and the Disorders of the Mind Depending on the Body, as in the full title of the book that was valued at fourpence in James's inventory, and in which "Lowness, Oppression or Anxiety" was a condition to be relieved by "Assafoetida" or "Peony-water." But the Johnstones also believed that the body was dependent on the mind, in respects that they discussed endlessly among themselves. "I know by Experience how much the Mind preys on the Body," James wrote to John, in 1771, and then, in 1772, the "Acidity of Life approaches;" "Depression of Mind is the most disagreeable attendant of advanced Life." "A Gentleman of his Acquaintance told me that he was more disordered in Mind than in Body," James wrote to their father, when their brother Alexander was convicted of mutiny on the West Indian island of Grenada.

"I have been much out of order in my Inward man," John wrote to his brother-in-law at the time of his wife's last illness, when he was in "constant pain" in his stomach and bowels. The siblings' uncle was invoked, as so often, when a nephew was reported to be in trouble; "Low 
Spirited people are not only very suspicious, but exceedingly quick sighted." Their mother wrote of their father that "All his ills [were] ever attended with great lowness of spirits." James was lavish, as ever, with counsel: "Betty is a Martyr to the delicate sensibility of Her Heart," "[George's] Body suffers for the Labor of his mind," and "Grieved am I every Time I think of my Dear John... Seventeen broiling years in Bengal is but Part of his Disorder": "Tranquillity of mind is more necessary for the Radical Cure of His Disease than keeping his feet constantly dry."

The art of medicine, in the 21 st century, exists in a tumultuous, continuously changing universe of physical, psychological, dietary, spiritual and pharmaceutical advice; our own "age of information.” The family doctor has been replaced by the primary care physician. But physicians -or the nurses and technicians and receptionists and insurance specialists and "patient advocates" by whom they are surrounded -- treat families as well as patients, and patients within their own social networks of friendship and family. Individuals live through illnesses within families and networks of friends, as well as in institutions. Goat whey is widely advertised, as a source of "naturally occurring macro and trace minerals," to "Enhance Mind \& Body!" Lowness and anxiety are relieved, still, with peony-water; valued, according to an online health condition index, for its “sedative and analgesic properties." There are many, like James Johnstone in 1771, who are preoccupied with "how much the Mind preys on the Body."

Thinking with history is a continuing exchange between the past and the present, in which observations of the present suggest questions about the past, and pieces of evidence about past lives suggest questions about our own circumstances. It is the outcome, thereby, of the "sympathetical affections" that Adam Smith described in his lectures on historical writing; of the collision of difference and closeness. Even the eighteenth-century Johnstones are people like us, whose illnesses 
and sentiments are recognizable in our modern, changing medical world. Their own histories of family health - in their sources of information, in their understanding of health as a condition of families, and in their preoccupation with the disorders of the mind - are a way of thinking about our times. 
Further Reading

Sunil Amrith, Decolonizing International Health: India and Southeast Asia, 1930-65 (London, 2006)

Kirsty Walker, "The Influenza Pandemic of 1918 in Southeast Asia,” in Sunil Amrith and Tim Harper, eds., Histories of health in Southeast Asia: Perspectives on the long twentieth century (Bloomington, IN, 2014)

Charles Rosenberg, "Back to the Future," The Lancet, Vol. 382, September 7, 2013

Emma Rothschild, The Inner Life of Empires: An Eighteenth-Century History (Cambridge, MA, 2012)

The Cullen Project: The Consultation Letters of Dr William Cullen (1710-1790)

http://www.cullenproject.ac.uk/ 